\title{
Diets of the Sympatric Pacific Sheath-Tailed Bat (Emballonura semicaudata rotensis) and Mariana Swiftlet (Aerodramus bartschi) on Aguiguan, Mariana Islands ${ }^{1}$
}

\author{
Ernest W. Valdez, ${ }^{2,5}$ Gary 7. Wiles, ${ }^{3}$ and Thomas 7. O'Shea ${ }^{4}$
}

\begin{abstract}
The Pacific sheath-tailed bat (Emballonura semicaudata rotensis) and Mariana swiftlet (Aerodramus bartschi) are two rare insectivorous taxa restricted to the southern Mariana Islands in western Micronesia. It is believed that populations of both have dwindled because of impacts to their food resources. However, there is little information on the food habits of $A$. bartschi and none exists for E. s. rotensis. In an effort to better understand the feeding habits of both, we investigated their diets using guano analysis. Guano was collected from two roosts in caves during a 2-week period in June and July at the onset of the rainy season. Important orders of insects consumed (percentage volume) by bats roosting at one cave included hymenopterans (64\%), coleopterans $(10 \%)$, lepidopterans $(8 \%)$, isopterans $(8 \%)$, and psocopterans $(5 \%)$, whereas those at a second cave included lepidopterans (45\%), hymenopterans (41\%), coleopterans $(10 \%)$, and isopterans (5\%). Swiftlets, which roosted in only one of the caves, fed mostly on hymenopterans (88\%) and hemipterans (6\%). Significant differences existed between the two taxa in several insect orders eaten, with E. s. rotensis consuming more lepidopterans and coleopterans and A. bartschi taking more hymenopterans and hemipterans. Within Hymenoptera, bats fed more on ichneumoideans, whereas swiftlets ate more formicid alates and chalicidoideans. This new information on the feeding habits of E. s. rotensis and A. bartschi provides insight on the complexity of their diets during June and July, and serves as baseline information for future studies and management of their habitat.
\end{abstract}

The PAcific sheath-tailed bat (Emballonura semicaudata rotensis) and Mariana swiftlet (Aerodramus bartschi) are cave-roosting aerial insectivores endemic to the five southernmost

\footnotetext{
${ }^{1}$ Primary funding for this study came from the U.S. Navy through an interagency agreement with the U.S. Fish and Wildlife Service and U.S. Geological Survey. Manuscript accepted 5 September 2010.

${ }^{2}$ U.S. Geological Survey, Fort Collins Science Center, Department of Biology, MSC03 2020, University of New Mexico, Albuquerque, New Mexico 87131-0001 (e-mail: ernie@usgs.gov).

${ }^{3}$ Washington Department of Fish and Wildlife, 600 Capitol Way North, Olympia, Washington 98501-1091.

${ }^{4}$ U.S. Geological Survey, Fort Collins Science Center, 2150 Centre Avenue, Building C, Fort Collins, Colorado 80526 .

${ }^{5}$ Corresponding author.
}

Pacific Science (2011), vol. 65, no. 3:301-309

doi: $10.2984 / 65.3 .301$

(C) 2011 by University of Hawai'i Press

All rights reserved
Mariana Islands of Guam, Rota, Aguiguan, Tinian, and Saipan in western Micronesia (Lemke 1986, Hutson et al. 2001, Cruz et al. 2008). Both taxa experienced severe declines in abundance during the twentieth century, including population extirpations on two or more islands within their limited ranges. Emballonura s. rotensis, which is one of four recognized subspecies of E. semicaudata (Koopman 1997), survives only on the small island of Aguiguan, where about 500 individuals occur (Hutson et al. 2001; G.J.W., T.J.O., D. J. Worthington, J. A. Esselstyn, and E.W.V., unpubl. data). Aerodramus bartschi remains only on Aguiguan, Saipan, and Guam (Cruz et al. 2008), with a small introduced population also present on O'ahu, Hawai'i (Wiles and Woodside 1999). Total population size in the Marianas was estimated at about 6,750 birds in 2008, including an estimated 300-400 on Aguiguan (Grimm 2008; P. Radley, unpubl. data; this study). Both species are 
categorized as endangered by the International Union for the Conservation of Nature and Natural Resources (IUCN 2009). Under the U.S. Endangered Species Act, A. bartschi is listed as endangered and E. s. rotensis is a candidate for listing.

Reasons for the population declines in both taxa are poorly understood but are perhaps related or compounded because of their similar foraging and cave-roosting habits. One or more of the following factors may have been involved in the declines: disturbance of caves, especially during World War II; loss or degradation of forests and other foraging habitats due to clearing for agriculture and other forms of development; loss of habitat due to introduction of ungulates and other invasive species; use of insecticides; typhoons; and predation by nonnative species such as rats (Rattus spp.), monitor lizards (Varanus indicus), and on Guam, brown tree snakes (Boiga irregularis [U.S. Fish and Wildlife Service 1991, Hutson et al. 2001, Cruz et al. 2008; G.J.W., T.J.O., D. J. Worthington, J. A. Esselstyn, and E.W.V., unpubl. data]).

Detailed knowledge of diet can benefit the conservation of rare species by providing critical information for evaluating life history, threats, and recovery actions. Kershner et al. (2007) conducted the only previous analysis of the food habits of $A$. bartschi, but no similar studies exist for $E$. semicaudata anywhere in its range. Our objectives were to determine and compare the diets of both species on Aguiguan, the only location where they continue to coexist.

\section{Study Area}

Aguiguan $\left(14^{\circ} 51^{\prime} \mathrm{N}, 145^{\circ} 33^{\prime} \mathrm{E}\right)$ is $7.2 \mathrm{~km}^{2}$ in size and formed entirely of raised limestone karst. Terrain is dominated by a large central plateau bordered by narrow terraces falling to the ocean, with elevation reaching $166 \mathrm{~m}$. The island's climate is tropical, with mean daily temperatures ranging from $24^{\circ} \mathrm{C}$ to $32^{\circ} \mathrm{C}$. Rainfall averages about $2,000 \mathrm{~mm}$ annually and occurs mainly from June to November. Plant communities consist of: (1) native limestone forest, which covers about $49 \%$
(G.J.W., T.J.O., D. J. Worthington, J. A. Esselstyn, and E.W.V., unpubl. data) of the island and is primarily composed of Guamia mariannae, Cynometra ramiflora, Pisonia grandis, Ochrosia mariannensis, Aglaia mariannensis, Ficus prolixa, Cerbera dilatata, and Premna obtusifolia; (2) former crop fields now largely revegetated by weedy thickets of introduced plants such as Lantana camara, Chromolaena odorata, Mikania scandens, Tridax procumbens, and several grasses (23\%); (3) groves of secondary forest composed mainly of introduced trees Acacia confusa, Leucaena leucocephala, Triphasia trifolia, and Casuarina equisetifolia and some native trees, including $O$. mariannensis, G. mariannae, and Melanolepis multiglandulosa (20\%); (4) grassy and shrubby coastal strand vegetation (4\%); and (5) bare ground (5\%). Decades of overbrowsing by feral goats (Capra bircus) have altered the structure and species composition of native forest and created an open understory with little ground cover. Aguiguan has been uninhabited since the end of World War II and is administered by the U.S. Commonwealth of the Northern Mariana Islands (CNMI).

\section{MATERIALS AND METHODS}

Examination of stomach contents is a useful method of determining food habits of insectivorous bats and birds (Rosenberg and Cooper 1990, Whitaker et al. 2009). This technique allows for the examination of undigested material and is especially beneficial for identifying soft insect parts that can be destroyed by digestion (Whitaker et al. 2009). However, direct analyses of stomach contents entails killing individuals immediately after capture, and there are often ethical and legal issues related to obtaining samples and an adequate number of samples needed for comparisons (Rosenberg and Cooper 1990, Whitaker et al. 2009). Therefore, given the respective rare and endangered status of $E$. $s$. rotensis and $A$. bartschi, we used the noninvasive method of guano analysis to determine diet composition of both taxa at two caves used as roost sites during June-July 2008. Analysis of guano provides an accurate method of identifying various hard-bodied 
(e.g., beetles) and soft-bodied (e.g., flies) insect prey items consumed and digested by bats (e.g., Valdez and Bogan 2009) and birds (e.g., Ralph et al. 1985), with good agreement in results when compared with stomach analyses (Whitaker et al. 1981, Waugh and Hails 1983). As with any diet analysis technique, the accuracy of guano analysis is dependent on expertise of the individual examining samples; available reference material; and the age, composition, and condition of the guano being examined.

Guano Cave was the larger of the two caves sampled and supported the largest and second largest known colonies of $A$. bartschi and $E$. s. rotensis, respectively, on Aguiguan, with $\geq 250$ nesting swiftlets and 43-64 bats (including females with volant young) counted during our visit to the island (G.J.W., T.J.O., D. J. Worthington, J. A. Esselstyn, and E.W.V., unpubl. data). Within the cave, areas of roost placement for each species were segregated, with roosting bats positioned about $15-20 \mathrm{~m}$ above the cave floor in a distinctive domed ceiling at the end of the deepest chamber of the cave, whereas most swiftlets and their nests occurred closer to the main entrance on the walls of the same chamber 3-15 $\mathrm{m}$ above the cave floor. This greatly reduced any crosscontamination of guano samples for each species collected during the study. Upon our initial observation of the guano in the cave, we found that piles from E. s. rotensis and A. bartschi had accumulated over many years and had largely disintegrated into a fine powder, making it difficult to distinguish bat from swiftlet guano. Therefore, we chose to collect fresh samples from E. s. rotensis and $A$. bartsch $i$ at the same time. On 25 June 2008, we placed a $1 \times 1 \mathrm{~m}$ plastic sheet on the cave floor directly beneath the roosting bats and a similar sheet beneath an area where swiftlets roosted. The sheets with accumulated fresh guano were retrieved from the cave floor on 30 June and placed in plastic resealable bags.

The second cave sampled, Crevice Cave, was located about $450 \mathrm{~m}$ from Guano Cave. It held a small group of E. s. rotensis (two to three adults, one pup) in a small side chute midway through the cave but showed no evidence of recent occupation by $A$. bartschi. On 27 June, we placed a $0.5 \times 0.5 \mathrm{~m}$ plastic sheet $1 \mathrm{~m}$ beneath the bats hanging on the wall of the cave. Because of the few bats present, we left the plastic sheet in place for 13 days to gather an adequate sample of guano.

We made a small reference collection of arthropods (mostly insects) to aid in identification of fragments observed during microscopic fecal analysis. Arthropods were collected using a sweep net and a black light, and by beating of vegetation with a hand net. We also collected a small sample of arthropods using sticky traps made of $76 \times 127 \mathrm{~mm}$ index cards coated with an insect barrier (Tree Tanglefoot Pest Barrier, The Tanglefoot Company, Grand Rapids, Michigan) and hung vertically from the forest canopy, but we abandoned this technique when seasonal rains caused disintegration of the cards. Collected arthropods were placed in vials of $95 \%$ ethanol and later identified in the laboratory. Guano and arthropod reference collections are held at the Museum of Southwestern Biology, University of New Mexico, Albuquerque, New Mexico.

Upon examination, we found that fresh fecal material of bats and swiftlets could be readily distinguished. The intact fecal pellets of $E$. s. rotensis were elliptical and averaged $4 \mathrm{~mm}$ long by $2 \mathrm{~mm}$ wide $(n=50)$, whereas those produced by $A$. bartschi were globular, as observed for other small insectivorous birds, and ranged in length from 6 to $24 \mathrm{~mm}$ $(\bar{x}=12 \mathrm{~mm}, n=50)$ and width from 3 to 14 $\mathrm{mm}(\bar{x}=7 \mathrm{~mm}, n=50)$. Guano from $A$. barts$c h i$ was also differentiated from $E$. s. rotensis guano by the presence of uric acid crystals combined with digested insect material. Microscopic inspection affirmed these gross differences; insect matter consumed by E. s. rotensis was always chewed into much smaller fragments than those found in $A$. bartschi fecal matter, and head capsules of insects were more prevalent in guano belonging to $A$. bartschi. Using these criteria, we sorted formed guano pellets of E. s. rotensis and $A$. bartschi from powdered guano that was created when the plastic sheeting was removed from the cave and transported to the laboratory. Samples were then grouped according to their respective roost or nest site. Pellets were 
subsampled and analyzed following the techniques of Whitaker et al. (2009). Fecal pellets were placed in watch glasses with $95 \%$ ethanol and teased apart under a stereo-zoom microscope. Insect prey were identified to the lowest taxonomic level possible, usually to family, using various guides for identification (Borror and White 1970, Chujo 1970, White 1983, Arnett 2000, Arnett and Thomas 2001, Arnett et al. 2002, Triplehorn and Johnson 2005, Clouse 2007, Whitaker et al. 2009).

One hundred intact fecal pellets of $E$. $s$. rotensis were analyzed from each roost, with each pellet representing one sample. Because fecal samples from $A$. bartschi disintegrated easily compared with bat guano, we were able to retrieve only 50 intact fecal samples for analyses. Percentage volume and frequency of occurrence were calculated for each prey item (Whitaker et al. 2009). In addition, we used digital calipers (Mitutoyo, Mitutoyo Corp., Japan) to measure length and width (to the nearest $0.01 \mathrm{~mm}$ ) of single representatives from our reference collection of arthropods that were similar in appearance to matched prey items found in the diet of E. s. rotensis and $A$. bartschi. Lengths were measured from the tip of the head or mandible, whichever extended farthest, to the end of the body. Widths were measured at the widest point of the head or body of the insect, excluding the legs and wings. Because we failed to collect voucher specimens of ichneumonoideans, we used the size of ichneumonoidean wings found in guano to estimate total size of the prey item and then measured a formicid of similar size to provide an approximate length and width. We did not collect any hymenopteran that could be used to estimate the size of Chalicidoidea.

We performed analyses of variance comparisons on food habits of E. s. rotensis and $A$. bartschi at Guano Cave using SAS 9.1. Results from Crevice Cave were used to assess general dietary differences between bat colonies but were excluded from statistical analyses because this colony's small size would likely have caused pseudoreplication among samples. Given the sizes of the E. s. rotensis and $A$. bartschi colonies at Guano Cave and on Aguiguan overall, we believe our sample sizes were large enough to provide a diluted representation of diet for each species without producing bias to any single individual in the sampled colonies. Also, we believe that statistical comparisons were best for samples collected under the same conditions and time frame, thus further excluding samples from bats in Crevice Cave.

\section{RESULTS}

We identified seven orders of insects in the diet of E. s. rotensis on Aguiguan. At Guano Cave, hymenopterans composed the greatest volume and frequency of occurrence in fecal pellets (Table 1). Among identified hymenopterans, ichneumonoideans (parasitic wasps) and the alates of Formicidae (ants) were most important as prey. Among formicids, members of the subfamilies Formicinae and Ponerinae were recorded and probably included the ponerine Anochetus graefferi (trap-jaw ant). Nearly half of the hymenopterans by volume were unidentified. Other common prey included coleopterans (beetles), microlepidopterans (moths), isopterans (termites), and psocopterans (barklice) (Table 1). Members of the coleopteran families Curculionidae (snout beetles), Cryptophagidae (silken fungus beetles), and Mordellidae (tumbling flower beetles) represented minor prey. Other identified prey items each composed $<1 \%$ of volume and did not occur frequently.

Fecal samples of E. s. rotensis from Crevice Cave contained mostly microlepidopterans and hymenopterans (Table 1). Within Hymenoptera, ichneumonoideans were consumed in the greatest amount, whereas alates of formicines and unidentified hymnopterans were eaten less often. Coleopterans and isopterans were also noteworthy prey. Among coleopterans, members of Cryptophagidae were the most important prey identified. Other identified prey items each composed $<1 \%$ of volume and did not occur frequently.

We identified six orders of insects in the diet of $A$. bartschi roosting at Guano Cave (Table 1). Hymenopterans were the main prey consumed, with alates of formicids, including Formicinae and Ponerinae, contributing most to the diet. Chalicidoideans (para- 
TABLE 1

Percentage Volume and Frequency of Occurrence of Prey Items in Guano Samples ( $n$ ) from Pacific Sheath-Tailed Bats (Emballonura semicaudata rotensis) and Mariana Swiftlets (Aerodramus bartschi) on Aguiguan, Mariana Islands, June-July 2008

\begin{tabular}{|c|c|c|c|c|c|c|}
\hline \multirow[b]{3}{*}{ Taxa } & \multicolumn{4}{|c|}{ E. s. rotensis } & \multirow{2}{*}{\multicolumn{2}{|c|}{$\begin{array}{c}\text { A. bartschi } \\
\begin{array}{c}\text { Guano Cave } \\
(n=50)\end{array}\end{array}$}} \\
\hline & \multicolumn{2}{|c|}{$\begin{array}{l}\text { Crevice Cave } \\
\quad(n=100)\end{array}$} & \multicolumn{2}{|c|}{$\begin{array}{l}\text { Guano Cave } \\
(n=100)\end{array}$} & & \\
\hline & $\%$ vol & $\%$ freq & $\%$ vol & $\%$ freq & \% vol & $\%$ freq \\
\hline Lepidoptera & 45 & 86 & $8^{*}$ & 38 & - $^{*}$ & - \\
\hline (Microlepidoptera) & 45 & 86 & $8^{*}$ & 38 & - $^{*}$ & - \\
\hline Hymenoptera & 41 & 82 & $64^{*}$ & 95 & $88^{*}$ & 100 \\
\hline Ichneumoidea & 31 & 46 & 25 & 45 & - & - \\
\hline Formicidae: Formicinae & 7 & 26 & 7 & 12 & 41 & 82 \\
\hline Formicidae: Ponerinae & & & 2 & 12 & 2 & 30 \\
\hline Chalicidoidea & - & - & - & - & 15 & 64 \\
\hline Unknown Hymenoptera & 3 & 18 & 31 & 63 & 30 & 90 \\
\hline Coleoptera & 10 & 68 & $10^{*}$ & 73 & $2^{*}$ & 78 \\
\hline Cryptophagidae & 3 & 18 & $<1$ & 4 & - & - \\
\hline Scolytinae & - & - & 1 & 9 & 1 & 42 \\
\hline Mordellidae & $<1$ & 6 & $<1$ & 3 & - & - \\
\hline Curculionidae & - & - & $<1$ & 2 & $<1$ & 2 \\
\hline Chrysomelidae & 1 & 1 & - & - & - & - \\
\hline Unknown Coleoptera & 6 & 53 & 8 & 60 & 1 & 54 \\
\hline Isoptera & 5 & 6 & 8 & 10 & 1 & 32 \\
\hline Diptera & $<1$ & 5 & $<1$ & 1 & $<1$ & 2 \\
\hline Hemiptera & $<1$ & 4 & $<1^{*}$ & 11 & $6^{*}$ & 32 \\
\hline Aradidae (Heteroptera) & - & - & - & - & 6 & 42 \\
\hline Cicadellidae (Auchenorrhyncha) & $<1$ & 2 & $<1$ & 4 & - & - \\
\hline Unknown Hemiptera & $<1$ & 2 & $<1$ & 7 & $<1$ & 4 \\
\hline Psocoptera & $<1$ & 2 & 5 & 26 & 1 & 32 \\
\hline Pseudocaecillidae & $<1$ & 2 & 5 & 26 & 1 & 32 \\
\hline Unknown insect & $<1$ & 20 & 1 & 10 & 1 & 12 \\
\hline Feather & 3 & 25 & 2 & 4 & - & - \\
\hline
\end{tabular}

Note: Values of each order represent the overall percentage volume (\% vol) and frequency (\% freq). Asterisks denote significant differences, at $95 \% \mathrm{CI}$, in percentage volumes of insect orders consumed by bats and swiftlets from Guano Cave only.

sitoid wasps) were the second most abundant and frequently encountered prey item. Unidentified hymenopterans, hemipterans, and coleopterans were also prominent in the diet. Among the two latter orders, prey items belonging to Aradidae (flat bugs) and Scolytinae (bark beetles) were recorded. Other insect orders each represented $\leq 1 \%$ of the volume and occurred in $2 \%-32 \%$ of fecal samples.

Significant differences existed in the percentage volumes of four insect orders consumed by E. s. rotensis and $A$. bartschi at Guano Cave (Table 1). Emballonura s. rotensis consumed larger amounts of lepidopterans $(F=$ 19.89; $\mathrm{df}=1,148 ; P<.01)$ and coleopterans $(F=6.79 ; \mathrm{df}=1,148 ; P=.01)$, whereas $A$. barts- chi consumed larger amounts of hymenopterans $(F=9.68 ; \mathrm{df}=1,148 ; P<.01)$ and hemipterans $(F=29.50 ; \mathrm{df}=1,148 ; P<.01)$.

Collected arthropods matching those consumed by E. s. rotensis were small in size, ranging from a scolytine at $1.72 \mathrm{~mm}$ long $\times 0.85$ $\mathrm{mm}$ wide to a ponerine at $7.6 \mathrm{~mm}$ long $\times 1.63$ $\mathrm{mm}$ wide (Table 2). Isopterans were the second largest prey item at $6.13 \mathrm{~mm}$ long $\times 1.55$ $\mathrm{mm}$ wide and would have been the longest at $11.87 \mathrm{~mm}$ if wings were included in the measurements. Arthropods consumed by $A$. bartsch $i$ were similar in size to those taken by E. s. rotensis, including scolytines, formicines, ponerines, and isopterans (Table 2). However, we suspect that larger-sized prey items may 


\section{TABLE 2}

Length and Width Measurements (to the Nearest $0.01 \mathrm{~mm}$ ) of a Single Representative from Some of the Prey Items Consumed by Pacific Sheath-Tailed Bats (Emballonura semicaudata rotensis) on Aguiguan, Mariana Islands, June-July 2008

\begin{tabular}{llc}
\hline \hline Insect & \multicolumn{1}{c}{ Length } & Width \\
\hline Ichneumonoidea $^{\text {Formicinae* }}$ & $3.38(4.15)$ & 0.73 \\
Ponerinae* $_{\text {Curculionidae }}$ & $5.10(6.07)$ & 1.20 \\
Scolytinae (large)* & $7.60(-)$ & 1.63 \\
Scolytinae (small) & 2.37 & 1.20 \\
Cryptophagidae & 1.57 & 0.95 \\
Mordellidae & 3.28 & 0.85 \\
Chrysomelidae & 3.32 & 1.50 \\
Microlepidoptera & 6.07 & 1.26 \\
Isoptera* & $2.69(3.14)$ & 3.91 \\
Pseudocaecillidae* & $6.13(11.87)$ & 0.94 \\
Cicadellidae & $2.75(3.36)$ & 1.55 \\
& $2.89(3.76)$ & 0.98 \\
\hline
\end{tabular}

Note: Asterisks denote prey item representatives also consumed by Mariana swiftlets (Aerodramus bartscbi). Numbers in parentheses represent the length of the head to the posterior tip of the wings. Measurements for Ichneumonoidea are estimated, based on measurements of a formicid with similar wing size.

be consumed based on the observed head lengths of aradids and other fragments of prey items found in this study.

\section{DISCUSSION}

Our study provides the first dietary data for E. s. rotensis, as well as new information on the food habits of $A$. bartschi. Hymenopterans, lepidopterans, and coleopterans were the main insect orders consumed by E. s. rotensis on Aguiguan, whereas $A$. bartschi primarily selected hymenopterans. To our knowledge, this study is also the first to compare the diets of sympatric populations of aerial insectivorous bats and swiftlets, which are sometimes considered ecological counterparts that exploit different periods of the day. Significant differences existed between the percentage volumes of four insect orders eaten by the two taxa at Guano Cave, with E. s. rotensis consuming more lepidopterans and coleopterans and $A$. bartschi taking more hymenopterans and hemipterans. Although Hymenoptera was the main insect order eaten by both taxa, E. s. rotensis targeted ichneumonoideans more than other identified families in the order, whereas $A$. bartschi fed more on formicids and chalicidoideans. Differences in prey selection between the two taxa likely result from differences in foraging behavior and the greater diurnal or nocturnal availability of some prey groups. Sampling for this study was conducted between late June and early July during the onset of the rainy season, which coincides with the birthing and pup rearing periods for E. s. rotensis (G.J.W., T.J.O., D. J. Worthington, J. A. Esselstyn, and E.W.V., unpubl. data) and the main breeding season for $A$. bartschi (Rice 1993; G.J.W., unpubl. data).

We detected localized differences in the diet of E. s. rotensis, with bats at Guano Cave consuming relatively more hymenopterans and fewer lepidopterans than those at Crevice Cave. At least two factors may have caused this. First, differences in the coverage of native and nonnative forest near each cave may have resulted in differences in insect abundance or availability for each colony. Second, results from Crevice Cave, where only two to three bats resided, may have been more strongly influenced by individual preferences in prey selection.

Members of the genus Emballonura are highly maneuverable fliers that commonly forage inside the cluttered understory of forests (Bonaccorso 1998). Gorresen et al. (2009) noted that the echolocation calls of $E$. $s . r o-$ tensis were typical of those of other species that forage close to and among the sonic "clutter" created by reflected echos from complex dense vegetation. Observations on Aguiguan indicate that E. s. rotensis does indeed concentrate much of its foraging activity in the understory but also feeds at treetop level and low above the forest canopy, and possibly in nonforested areas (Esselstyn et al. 2004, Gorresen et al. 2009). Because of the relatively short stature (7-15 $\mathrm{m}$ tall) of the island's native forest, most understory foraging by $E$. s. rotensis occurs within $5-6 \mathrm{~m}$ of the ground. By comparison, A. bartschi mostly forages low over native forest (including around the crowns of emergent trees) and along forest edges bordering fields and other openings on Aguiguan, and rarely if ever feeds in forest interiors (G.J.W., pers. obs.). Large open areas on Aguiguan are infrequently used. 
The only other detailed dietary information for another species of Emballonura exists for E. nigrescens, which has been found to prey commonly on ants (Vestjens and Hall 1977). Coleura seychellensis, another emballonurid with a body size similar to that of E. s. rotensis that is also restricted to oceanic islands, feeds primarily on lepidopterans, coleopterans, and to a lesser extent on hymenopterans while showing greater plasticity in diet and habitat use than E. s. rotensis (Gerlach and Taylor 2006).

Our dietary findings for $A$. bartschi are partially consistent with those of Kershner et al. (2007), who reported that hymenopterans composed $60 \%-65 \%$ of the total insect parts examined in guano from Saipan during the wet and dry seasons, with winged formicids being the most common identified prey group in that order. However, two other important prey groups on Saipan (coleopterans, 20\%$23 \%$ of diet in both seasons; homopterans [= Auchenorrhyncha], 10\%, wet season) were only eaten in small amounts or not recorded on Aguiguan. Cursory examination of guano from $A$. bartschi on Guam indicates that flying ants are the primary dietary component on that island as well, with unidentified weevils and other coleopterans present in far smaller amounts (R. Muniappan, pers. comm.). Hymenopterans are well documented as a major food of some other species of swiftlets (Langham 1980, Hails and Amirrudin 1981, Tarburton 1986, 1993, Lourie and Tompkins 2000), with winged formicids being particularly important at some locations (Harrisson 1974, Lim and Earl of Cranbrook 2002, Nguyen Quang et al. 2002). A number of other insect orders are often prominent in the diet of swiftlets, including dipterans, coleopterans, and hemipterans (Langham 1980, Hails and Amirrudin 1981, Lourie and Tompkins 2000).

In some fecal pellets of E. s. rotensis, we found fragments of coleopterans degraded into a pastelike texture. This suggests the presence of chitinase, a digestive enzyme produced by bacteria in the gastrointestinal tracts of some species of bats that aids the breakdown of chitinous insect parts and possibly helps in the separation of these parts from softer connective tissues (Whitaker et al.
2004). Although not yet confirmed in tropical bats, chitinase would be potentially beneficial during periods when food resources are low or preferred items are unavailable. We found no evidence of chitinase or related types of digestion in the guano of $A$. bartschi. One of the more interesting items found within some pellets of E. s. rotensis was the presence of small, nearly microscopic fragments of feathers. These fragments were digested, embedded within the fecal pellet, and found only after pellets were teased apart. Fragments included parts of barbs of small feathers, likely belonging to $A$. bartschi. We believe small feathers or feather fragments in the air were most likely confused for small insect prey and consumed mistakenly by E. s. rotensis while in the roost cave as bats and birds exited and returned from their foraging sorties. Another hypothesis is that feather fragments and other small airborne particulates landed on the bats' fur and were consumed inadvertently during grooming.

Detection of Cryptophagidae and Pseudocaecillidae in our study supports the findings of Esselstyn et al. (2004) and Gorresen et al. (2009) that E. s. rotensis is strongly reliant on forested habitats for foraging on Aguiguan. Cryptophagids feed on fungi and decaying plant matter, and live in decaying plants, whereas pseudocaecillids live in bark or foliage of trees and shrubs, beneath bark, and in dead leaves (Triplehorn and Johnson 2005), all of which are associated with forest habitat on Aguiguan.

In a dietary study of four sympatric swiftlets in Malaysia, Lourie and Tompkins (2000) found that ants and fig wasps composed most of the diet for those birds. They reported that flying ants composed $85 \%$ of the diet for black-nest swiftlets (A. maximus) from forested locations. They further reported that the food habits of the glossy swiftlet (Collocalia esculenta) varied greatly in a comparison of forest, rural, and urban habitats, with diets from forest habitat having greater abundance of hymenopterans. These examples suggest that hymenopterans in the diet of some swiftlets, as well as the presence of other insects (e.g., Aradidae and Scolytinae, this study), are more abundant or are more associated with forested habitats. Therefore like E. s. rotensis, 
A. bartschi on Aguiguan may be reliant on native forests for foraging.

Because our sampling was restricted to a 2 -week period, we undoubtedly did not record the full diversity of arthropods eaten year-round and at other locations (e.g., nonforested habitat) on Aguiguan and thus may have missed other seasonally important or habitat-specific prey types. Greater variation in dietary choice would be expected, especially in response to differing phenologies of prey throughout the year. A lack of information on the seasonality of most of the prey groups identified in this study makes it difficult to predict important foods during other parts of the year in the Marianas (I. Schreiner, pers. comm.). We recommend more extensive dietary studies on E. s. rotensis and A. bartschi during other periods of the year, and recommend that these studies coincide with investigations on the phenologies and habitat use of insect prey throughout Aguiguan.

\section{ACKNOWLEDGMENTS}

We thank E. Masga, F. Muna, M. Gorresen, F. Bonaccorso, D. Evangalista, T. Castro, J. Omar, G. Comacho, J. Salas, and the rest of the field crew for their help. We also thank C. Kessler, S. Igisomar, and the CNMI Department of Land and Natural Resource offices on Saipan and Tinian for their logistic support. We extend our gratitude to K. Miller, N. Lord, A. Johnson, and S. Brantley for their insight and assistance on arthropod identification. N. Johnson, I. Schreiner, and P. Radley gave additional assistance. We thank P. Cryan and A. Brooke for their comments on early drafts. Any use of trade, product, or firm names in this publication is for descriptive purposes only and does not imply endorsement by the U.S. Government.

\section{Literature Cited}

Arnett, R. H., Jr. 2000. American insects: A handbook of insects north of Mexico. 2nd ed. CRC Press, Boca Raton, Florida.

Arnett, R. H., Jr., and M. C. Thomas. 2001. American beetles, Archostemata, Myxophaga, Adephaga, Polyphaga: Staphylinifor- mia. Vol. 1. CRC Press, Boca Raton, Florida.

Arnett, R. H., Jr., M. C. Thomas, P. E. Skelley, and J. H. Frank. 2002. American beetles, Polyphaga: Scarabaeoidea through Curculionidea. Vol. 2. CRC Press, Boca Raton, Florida.

Bonaccorso, F. J. 1998. Bats of Papua New Guinea. Conservation International, Washington, D.C.

Borror, D. J., and R. E. White. 1970. A field guide to insects of America north of Mexico. Houghton Mifflin Company, Boston, Massachusetts.

Chujo, M. 1970. Coleoptera: Cryptophagidae and Mycetophagidae. Insects Micronesia 16:271-278.

Clouse, R. M. 2007. The ants of Micronesia (Hymenoptera: Formicidae). Micronesica 39:171-295.

Cruz, J. B., S. R. Kremer, G. Martin, L. L. Williams, and V. A. Camacho. 2008. Relative abundance and distribution of Mariana swiftlets (Aves: Apodidae) in the Northern Mariana Islands. Pac. Sci. 62: 233-246.

Esselstyn, J. A., G. J. Wiles, and A. Amar. 2004. Habitat use of the Pacific sheathtailed bat (Emballonura semicaudata) on Aguiguan, Mariana Islands. Acta Chiropt. 6:303-308.

Gerlach, J., and M. Taylor. 2006. Habitat use, roost characteristics and diet of the Seychelles sheath-tailed bat Coleura seychellensis. Acta Chiropt. 8:129-139.

Gorresen, P. M., F. J. Bonaccorso, and C. A. Pinzari. 2009. Habitat occupancy and detection of the Pacific sheath-tailed bat (Emballonura semicaudata) on Aguiguan, Commonwealth of the Northern Mariana Islands. Acta Chiropt. 11:331-342.

Grimm, G. 2008. Mariana swiftlet surveys on Naval Munitions Site, Guam. Naval Facility Marianas, Guam.

Hails, C. J., and A. Amirrudin. 1981. Food samples and selectivity of white-bellied swiftlets Collocalia esculenta. Ibis 123:328333.

Harrisson, T. 1974. The food of Collocalia swiftlets (Aves, Apodidae) at Niah Great Cave in Borneo. J. Bombay Nat. Hist. Soc. 71:376-393. 
Hutson, A. M., S. P. Mickleburgh, and P. A. Racey. 2001. Microchiropteran bats: Global status survey and conservation plan. IUCN, IUCN/SSC Chiropteran Specialist Group, Gland, Switzerland and Cambridge, United Kingdom.

IUCN. 2009. IUCN Red list of threatened species, version 2009.1. International Union for Conservation of Nature and Natural Resources, Gland, Switzerland (http://www.iucnredlist.org/) (accessed 21 August 2009).

Kershner, E. L., R. Kohley, B. Hudgens, and D. K. Garcelon. 2007. Assessment of Mariana swiftlet (Aerodramus bartschi) diet and insect availability on Saipan and Rota, Mariana Islands. Unpublished report. Institute for Wildlife Studies, Arcata, California (www.iws.org).

Koopman, K. F. 1997. The subspecies of Emballonura semicaudata (Chiroptera: Emballonuridae). J. Mammal. 78:358-360.

Langham, N. 1980. Breeding biology of the edible-nest swiftlet Aerodramus fuciphagus. Ibis 122:447-461.

Lemke, T. O. 1986. Distribution and status of the sheath-tailed bat (Emballonura semicaudata) in the Mariana Islands. J. Mammal. 67:743-746.

Lim, C. K., and Earl of Cranbrook. 2002. Swiftlets of Borneo: Builders of edible nests. Natural History Publications (Borneo), Kota Kinabalu, Malaysia.

Lourie, S. A., and D. M. Tompkins. 2000. The diets of Malaysian swiftlets. Ibis 142:596-602.

Nguyen Quang, P., Y. Vo Quang, and J.-F. Voisin. 2002. The white-nest swiftlet and the black-nest swiftlet: A monograph. Société Nouvelle des Éditions Boubée, Paris, France.

Ralph, C. P., S. E. Nagata, and C. J. Ralph. 1985. Analysis of droppings to describe diets of small birds. J. Field Ornithol. 56:165-174.

Rice, C. G. 1993. Island swiftlet research. Pages 241-255 in Five-year progress report, fiscal years 1988-1992, PittmanRobertson Federal Aid in Wildlife Restoration Program. Division of Fish and Wildlife, Commonwealth of the Northern Mariana Islands, Saipan.
Rosenberg, K. V., and R. J. Cooper. 1990. Approaches to avian diet analysis. Stud. Avian Biol. 13:80-90.

Tarburton, M. K. 1986. The food of the white-rumped swiftlet (Aerodramus spodiopygius) in Fiji. Notornis 33:1-16.

. 1993. The diet of the white-rumped swiftlet (Aerodramus spodiopygius) in Queensland's savannah. Avocetta 17:125129.

Triplehorn, C. A., and P. J. Johnson. 2005. Borror and Delong's introduction to the study of insects. 7th ed. Brooks Cole Publishing, Belmont, California.

U.S. Fish and Wildlife Service. 1991. Recovery plan for the Mariana Islands population of the Vanikoro swiftlet, Aerodramus vanikorensis bartschi. U.S. Fish and Wildlife Service, Portland, Oregon.

Valdez, E. W., and M. A. Bogan. 2009. Does variation in cranial morphology of Myotis occultus (Chiroptera: Vespertilionidae) reflect a greater reliance on certain prey types? Acta Chiropt. 11:443-450.

Vestjens, W. J. M., and L. S. Hall. 1977. Stomach contents of forty-two species of bats from the Australasian region. Aust. Wildl. Res. 4:25-35.

Waugh, D. R., and C. J. Hails. 1983. Foraging ecology of a tropical aerial feeding bird guild. Ibis 124:200-217.

Whitaker, J. O., Jr., H. K. Dannelly, and D. A. Prentice. 2004. Chitinase in insectivorous bats. J. Mammal. 85:15-18.

Whitaker, J. O., Jr., C. Maser, and S. P. Cross. 1981. Food habits of eastern Oregon bats, based on stomach and scat analyses. Northwest Sci. 55:281-292.

Whitaker, J. O., Jr., G. F. McCracken, and B. M. Siemers. 2009. Food habits analysis of insectivorous bats. Pages 567-592 in T. H. Kunz, ed. Ecological and behavioral methods for the study of bats. 2nd ed. Smithsonian Institution Press, Washington, D.C.

White, R. E. 1983. A field guide to the beetles of North America. Houghton Mifflin Company, Boston, Massachusetts.

Wiles, G. J., and D. H. Woodside. 1999. History and population status of Guam swiftlets on O'ahu, Hawai'i. 'Elepaio 59: $57-61$. 
